Arch.Tierz., Dummerstorf 48 (2005) 5, 445-459

Humboldt-Universität zu Berlin, Institute of Animal Sciences, Department of Animal Breeding in the Tropics and Subtropics, Germany

LUTFI M.-A. MUSA, MOHAMED-KHAIR A. AHMED, KURT J. PETERS, BIRGIT ZUMBACH and KAMAL E. A. GUBARTALLA

\title{
The reproductive and milk performance merit of Butana cattle in Sudan
}

\author{
Dedicated to Prof. Dr. Peter Horst on the occasion of his $75^{\text {th }}$ birthday
}

\begin{abstract}
Data from the Butana herd of Atbara Livestock Research Station were analyzed for the period 1949 - 1999. The least squares means for age at first calving, calving interval, milk yield per lactation, daily milk yield, lactation length and dry period were $45.05 \pm 3.56$ months, $382.38 \pm 8.30$ days, $1662.57 \pm 108.96 \mathrm{~kg}, 6.10 \pm 0.40 \mathrm{~kg}$, $268.17 \pm 5.56$ days and $119.10 \pm 8.30$ days, respectively.

The analysis of variance revealed that the sire and parity number influenced the studied traits, while year-season of calving influenced the milk yield per lactation, daily milk yield and lactation length. Linear and quadratic regressions on lactation length significantly influenced milk yield per lactation and daily milk yield.

Heritability estimates for age at first calving, calving interval, milk yield per lactation, daily milk yield, lactation length and dry period were $0.19 \pm 0.07,0.09 \pm 0.03,0.26 \pm 0.06,0.27 \pm 0.07,0.04 \pm 0.02$, and $0.09 \pm 0.03$, respectively.

This study highlighted the importance of conserving the indigenous dairy cattle breeds for future generations. The presence of significant variation and the corresponding heritability estimates give promise of reasonable genetic improvement under selective breeding with respect to milk yield characters.
\end{abstract}

Key Words: Butana cattle, reproduction performance, milk yield

\section{Zusammenfassung}

Titel der Arbeit: Reproduktions- und Milchleistungen von Butana Rindern im Sudan

Leistungsdaten von Butana-Zuchtherden auf der Atbara Livestock Station aus den Jahren 1949-1999 wurden zur Berechnung der Laktationsleistung, tägliche Milchmenge, Laktationslänge, Trockenstehzeit, Erstkalbealter und Kalbeintervall herangezogen $(1662,57 \pm 108,96 \mathrm{~kg}, 6,10 \pm$ 0,40 kg, 268,17 \pm 5,56 Tage, 119,10 \pm 8,30 Tage, 45,05 \pm 3,56 Monate und 382,38 \pm 8,30 Tage).

Jahr und Saison der Kalbung und Laktationsnummer beeinflussten alle Leistungsmerkmale außer Trockenperiode und Zwischenkalbezeit. Die Regression ersten und zweiten Grades der Laktationslänge auf die Laktationsleistung war signifikant und auf die tägliche Milchleistung hochsignifikant.

Heritabilitäts-Schätzwerte für Erstkalbealter, Zwischenkalbezeit, Laktationsleistung, tägliche Milchleistung, Laktationslänge und Trockenstehzeit waren $0,19 \pm 0,07,0,09 \pm 0,03,0,26 \pm 0,06,0,27 \pm 0,07,0,04 \pm 0,02$ und $0,09 \pm 0,03$.

Die Studie hebt die Bedeutung einer nutzungsorientierten Erhaltung der Butana Milchrinder hervor. Die vorhandene Leistungsvariabilität und geschätzte Heritabilität lassen eine erfolgreiche züchterische Verbesserung durch Reinzucht erwarten.

Schlüsselwörter: Butana Rinder, Fruchtbarkeit, Milchleistung

\section{Introduction}

Livestock play important roles for production of food and represent great socioeconomic and cultural values in various societies around the world. Indigenous cattle form the backbone of relevant and sustainable livestock production in most Eastern 
African countries because when compared with their exotic counterparts, they are better adapted to survive and reproduce under the region's harsh environments (OKOMO-ADHIAMBO, 2002).

In Sudan, the rural communities own $80 \%$ of the livestock and the nomadic tribes own $90 \%$ of the rural holdings with livestock playing a central role in their livelihoods. Attempts to infuse exotic improved blood into Sudanese dairy cattle population led in some cases to the extinction or near-extinction of the best local types of cattle (Butana and Kenana) in some areas of the country. Through experience, many herdsmen have come to understand that the best results are obtained by crossing the best local cattle (usually Butana and Kenana) with the exotic breeds (usually Friesian).

This has led to widespread concern over the fate of Butana and Kenana types and to efforts for conservation of these strains for both present and future use. This concern is motivated by the fact that the genotypes of the improved indigenous breeds may be required to upgrade or replace low producing cattle in harsh nomadic environments where exotic cattle cannot survive. Another cause for concern is the fact that the directions of future demand cannot be predicted with any certainty. Research, to improve the knowledge on indigenous animal genetic resources, is instrumental for increased awareness on the role of livestock and their genetic diversity and for the implementation of sustainable breeding programmes.

This study was conducted to estimate genetic parameters for some important productive traits including milk yield per lactation, daily milk yield, lactation length, dry period, calving interval and age at first calving of Butana cattle of Sudan. The effects of some environmental factors are also investigated. This is important for the success of any attempt to explore the possibilities of improvement and conservation of this local breed, which is now threatened by extensive and unplanned crossing with foreign breeds.

\section{Material and Methods}

The data used in this study were extracted from Atbara Livestock Research Station records. They included 1894 records of 562 Butana cows covering the years 1949 1999. The data were classified into five periods according to the year of calving and according to the year of birth of the cow. Each period extended for ten years. Table 1 shows the distribution of animals over the years according to the year of birth of the cow.

\section{Table 1}

The distribution of animals over the years according to the year of birth of the cow (Die Verteilung der Tiere nach dem Geburtsjahr der Kuh)

\begin{tabular}{lc}
\hline Years & Number of cow \\
\hline $1949-1958$ & 27 \\
$1959-1968$ & 160 \\
$1969-1978$ & 241 \\
$1979-1988$ & 104 \\
$1989-1999$ & 30 \\
\hline Total & 562 \\
\hline
\end{tabular}


The station is situated in the River Nile State in Northern Sudan. It is located at $17^{\prime} 42^{\circ}$ $\mathrm{N}$ latitude and $33^{\prime} 58^{\circ} \mathrm{E}$ longitude at an altitude of approximately 345 meters above sea level and an average annual precipitation of $70 \mathrm{~mm}$. The atmospheric temperature in this area varies from a maximum of $47.7^{\circ} \mathrm{C}$ recorded in April, to a minimum of 4.5 ${ }^{\circ} \mathrm{C}$ registered in January.

Mixed model least-squares and maximum likelihood analysis were performed for each trait to compute least squares means, standard errors and coefficients of variation using HARVEY's computer programme (1990).

The following statistical models were applied.

Model (1)

Analysis of age at first calving:

$Y_{j k}=\mu+C_{j}+S_{k}+e_{j k}$

Where

$\mathrm{Y}_{\mathrm{ijk}}=$ the $_{\mathrm{ijk}}$ th observation of the trait in question

$\mu=$ the overall mean

$\mathrm{C}_{\mathrm{j}}=$ effect of $\mathrm{j}^{\mathrm{th}}$ year-season of cow's birth $(\mathrm{j}=1-15)$

$\mathrm{S}_{\mathrm{k}}=$ effect of $\mathrm{k}^{\text {th }}$ sire of cow $(\mathrm{k}=1-21)$

$\mathrm{e}_{\mathrm{ijk}}=$ residual error

Model (2)

Analysis of dry period and calving interval

$\mathrm{Y}_{\mathrm{ijkl}}=\mu+\mathrm{R}_{\mathrm{i}}+\mathrm{C}_{\mathrm{j}}+\mathrm{S}_{\mathrm{k}}+\mathrm{b}_{1} \mathrm{~A}+\mathrm{e}_{\mathrm{ijkl}}$

Where

$\mathrm{C}_{\mathrm{j}}=$ effect of $\mathrm{j}^{\text {th }}$ year-season of calving $(\mathrm{j}=1-15)$

$\mathrm{R}_{\mathrm{I}}=$ effect of $\mathrm{i}^{\text {th }}$ parity number $(\mathrm{i}=1-5)$

$\mathrm{A}=$ lactation length

$\mathrm{b}_{1}=$ linear regression coefficient

$\mathrm{Y}_{\mathrm{ijkl}}, \mu, \mathrm{S}_{\mathrm{k}}$, and $\mathrm{e}_{\mathrm{ijkl}}$ as in model (1) above

Model (3)

Analysis of milk yield per lactation and daily milk yield

$\mathrm{Y}_{\mathrm{ijkl}}=\mu+\mathrm{R}_{\mathrm{i}}+\mathrm{C}_{\mathrm{j}}+\mathrm{S}_{\mathrm{k}}+\mathrm{b}_{1} \mathrm{~A}+\mathrm{b}_{2} \mathrm{~A}^{2}+\mathrm{e}_{\mathrm{ijkl}}$

Where

$\mathrm{b}_{2}=$ quadratic regression coefficient

$\mathrm{Y}_{\mathrm{ijkl}}, \mu, \mathrm{C}_{\mathrm{j}}, \mathrm{R}_{\mathrm{I}}, \mathrm{A}, \mathrm{b}_{1}, \mathrm{~S}_{\mathrm{k}}$, and $\mathrm{e}_{\mathrm{ijkl}}$ as in model (1 and 2) above

Model (4)

Analysis of lactation length:

$Y_{i j k l}=\mu+R_{i}+C_{j}+S_{k}+b_{1} D+b_{2} D^{2}+e_{i j k l}$

Where

$\mathrm{D}=$ daily milk yield

$\mathrm{Y}_{\mathrm{ijkl}}, \mu, \mathrm{R}_{\mathrm{i}}, \mathrm{C}_{\mathrm{j}}, \mathrm{S}_{\mathrm{k}}, \mathrm{b}_{1}, \mathrm{~b}_{2}$ and $\mathrm{e}_{\mathrm{ijkl}}$ as in model (1, 2and 3) above

The heritabilities were estimated by paternal half-sib variance analysis as described by BECKER (1975). Data were analyzed using HARVEY's computer programme (1990). Differences between means were tested using Duncan's Multiple Range Test (DMRT). 
Results

The results (Table 2, 3, and 4) indicated that the sire of cow and parity number had significant $(\mathrm{p}<0.05)$ influences on all studied traits, while year-season of calving influenced $(\mathrm{p}<0.05)$ milk yield per lactation, daily milk yield and lactation length. Linear and quadratic regressions on lactation length had significant $(p<0.05)$ effects on milk yield per lactation and daily milk yield. The results also showed that the linear and quadratic regressions on daily milk yield had a significant influence on lactation length. In addition, the results revealed that the linear regression on lactation length had a significant $(\mathrm{p}<0.001)$ effect on dry period.

Table 2

Least squares means and standard errors of age at first calving (model 1) (LSQ-Mittelwert der Erstkalbealter bei Butana-Rindern)

\begin{tabular}{|c|c|c|}
\hline Items & n (522) & $\begin{array}{l}\text { Age at first calving } \\
\text { L.S.M } \pm \text { S.E. (months) }\end{array}$ \\
\hline Overall mean & & $45.05 \pm 3.56$ \\
\hline Sire & & $* * *$ \\
\hline Year-season of calving & & $* *$ \\
\hline $1949-1958$ & 14 & $39.73 \pm 5.52$ \\
\hline Dry summer & 10 & $34.96 \pm 6.64$ \\
\hline Wet summer & 11 & $46.82 \pm 6.60$ \\
\hline $1959-1968$ & 59 & $43.07 \pm 5.16$ \\
\hline Dry summer & 51 & $40.36 \pm 5.22$ \\
\hline Wet summer & 34 & $41.27 \pm 4.56$ \\
\hline $1969-1978$ & 74 & $47.27 \pm 4.18$ \\
\hline Dry summer & 91 & $44.83 \pm 4.57$ \\
\hline Wet summer & 42 & $43.27 \pm 4.63$ \\
\hline $1979-1988$ & 31 & $50.36 \pm 5.21$ \\
\hline Dry summer & 33 & $50.94 \pm 5.36$ \\
\hline Wet summer & 33 & $49.04 \pm 5.25$ \\
\hline Winter $\quad 1989-1999$ & 13 & $46.11 \pm 6.15$ \\
\hline Dry summer & 12 & $47.71 \pm 6.65$ \\
\hline Wet summer & 14 & $50.87 \pm 6.52$ \\
\hline Coefficient of variation & & $17.23 \%$ \\
\hline
\end{tabular}

L.S.M = least squares means $\quad$ S.E. = standard error $n=$ total number of observations

Means without a common superscript differ significantly $(\mathrm{p}<0.05)$

(Winter $=$ November - February, Dry summer $=$ March - June \& Wet summer $=$ July - October $)$

$* *=\mathrm{p}<0.001 \quad * * *=\mathrm{p}<0.0001$

The estimated least squares means for age at first calving (Table 2) is $45.09 \pm 3.56$ months, with a coefficient of variation of $17.23 \%$. The results also showed an increasing age at first calving over years and this has become more marked from the late seventies on.

The overall calving interval (Table 3) was estimated as $382.38 \pm 8.30$ days, with a coefficient of variation of $17.87 \%$. The effect of parity number showed a shortening of the interval with advancing parity number. The results also indicated that cows in the first parity had a significantly $(\mathrm{p}<0.05)$ longer calving interval $(404.65 \pm 8.99$ days) than those in the other parities. 
Table 3

Least squares means and standard errors of calving interval and dry period (model 2) (LSQ-Mittelwerte der Zwischenkalbezeit und Trockenstehzeiten bei Butana Rindern)

\begin{tabular}{|c|c|c|c|c|}
\hline \multicolumn{2}{|l|}{ Items } & $\mathrm{n}=(996)$ & \multicolumn{2}{|c|}{ L.S.M \pm S.E (days) } \\
\hline \multicolumn{3}{|c|}{ Overall mean } & $382.38 \pm 8.30$ & $119.10 \pm 8.30$ \\
\hline \multicolumn{3}{|l|}{ Sire } & $* *$ & $* *$ \\
\hline \multicolumn{3}{|l|}{ Parities } & $* *$ & $* *$ \\
\hline \multicolumn{2}{|c|}{ First parity } & 269 & $404.65 \pm 8.99^{\mathrm{a}}$ & $141.37 \pm 8.99^{\mathrm{a}}$ \\
\hline \multicolumn{2}{|c|}{ Second parity } & 280 & $375.66 \pm 8.91^{b}$ & $112.38 \pm 8.91^{\mathrm{b}}$ \\
\hline \multicolumn{2}{|c|}{ Third parity } & 249 & $374.86 \pm 9.08^{\mathrm{b}}$ & $111.58 \pm 9.08^{\mathrm{b}}$ \\
\hline \multicolumn{2}{|c|}{ Fourth parity } & 198 & $374.36 \pm 9.48^{\mathrm{b}}$ & $111 . .08 \pm 9.48^{\mathrm{b}}$ \\
\hline \multicolumn{3}{|c|}{ Year-season of calving } & n.s & n.s \\
\hline Winter & $1949-1958$ & 12 & $370.47 \pm 23.45$ & $107.18 \pm 23.45$ \\
\hline \multicolumn{2}{|c|}{ Dry summer } & 11 & $366.50 \pm 24.38$ & $103.18 \pm 24.38$ \\
\hline \multicolumn{2}{|c|}{ Wet summer } & 11 & $355.74 \pm 22.77$ & $92.46 \pm 22.77$ \\
\hline Winter & $1959-1968$ & 79 & $364.13 \pm 12.81$ & $100.85 \pm 12.81$ \\
\hline \multicolumn{2}{|c|}{ Dry summer } & 136 & $364.77 \pm 11.69$ & $101.49 \pm 11.69$ \\
\hline \multicolumn{2}{|c|}{ Wet summer } & 37 & $357.27 \pm 14.58$ & $93.99 \pm 14.58$ \\
\hline Winter & $1969-1978$ & 121 & $381.09 \pm 10.82$ & $117.81 \pm 10.82$ \\
\hline \multicolumn{2}{|c|}{ Dry summer } & 149 & $387.08 \pm 10.44$ & $123.80 \pm 10.43$ \\
\hline \multicolumn{2}{|c|}{ Wet summer } & 84 & $390.98 \pm 11.32$ & $127.69 \pm 11.32$ \\
\hline Winter & $1979-1988$ & 113 & $388.68 \pm 12.02$ & $125.40 \pm 12.02$ \\
\hline \multicolumn{2}{|c|}{ Dry summer } & 94 & $398.04 \pm 12.21$ & $134.76 \pm 12.21$ \\
\hline \multicolumn{2}{|c|}{ Wet summer } & 65 & $392.92 \pm 13.08$ & $129.64 \pm 13.09$ \\
\hline Winter & $1989-1999$ & 43 & $394.64 \pm 17.14$ & $131.36 \pm 17.14$ \\
\hline \multicolumn{2}{|c|}{ Dry summer } & 18 & $410.72 \pm 21.31$ & $147.44 \pm 21.31$ \\
\hline \multicolumn{2}{|c|}{ Wet summer } & 23 & $412.71 \pm 20.95$ & $149.43 \pm 20.95$ \\
\hline \multicolumn{3}{|c|}{ Linear regression on lactation length } & $0.33566 \pm 0.02659 * * *$ & $-0.6643 \pm 0.0266 * * *$ \\
\hline \multicolumn{3}{|c|}{ Coefficient of variation } & $17.87 \%$ & $68.90 \%$ \\
\hline \multicolumn{4}{|c|}{$\begin{array}{l}\text { L.S.M = least squares means } \\
\text { Means without a common superscript differ significantly }(p<0.05)\end{array}$} & vations \\
\hline
\end{tabular}

The overall mean of dry period was $119.10 \pm 8.30$ days (Table 3) with a coefficient of variation of $68.90 \%$. Advanced parity numbers resulted in a shortening of the dry period, and cows in the first parity had a significantly $(\mathrm{p}<0.05)$ longer dry period (141.37 \pm 8.99 days) than those in later parities.

The overall mean for milk yield per lactation (Table 4) was $1662.57 \pm 108.96 \mathrm{~kg}$, with a coefficient of variation of $37.22 \%$. The results also revealed that the yield increased with advancing parity number and that the maximum milk yield per lactation was reached after the fifth parity $(1805.97 \pm 112.61)$. The milk yield after the fifth parity was significantly $(p<0.05)$ higher than the yield after the first, second and third parities, while it was similar ( $>0.05)$ to the yield in the fourth lactation. The milk yield after the first parity was significantly $(\mathrm{p}<0.05)$ lower than after all other parities. 
The linear regression coefficient on lactation length was $6.38 \pm 0.151$ while the quadratic regression was found to be negative and small $(-0.0045 \pm 0.001)$.

Table 4

Least squares means and standard errors of milk yield per lactation, daily milk yield and lactation length (models 3 and 4) (LSQ-Mittelwerte der Milchleistung und Laktationslänge bei Butana Rindern)

\begin{tabular}{|c|c|c|c|c|c|}
\hline \multicolumn{2}{|l|}{ Items } & $n=(1574)$ & $\begin{array}{l}\text { Milk yield per } \\
\text { lactation } \\
\text { L.S.M } \pm \mathrm{S}\end{array}$ & $\begin{array}{l}\text { Daily milk yield } \\
\text { (kg) }\end{array}$ & $\begin{array}{c}\text { Lactation length } \\
\text { L.S.M } \pm \text { S.E (days) }\end{array}$ \\
\hline \multicolumn{2}{|c|}{ Overall mean } & & $1662.57 \pm 108.96$ & $6.10 \pm 0.41$ & $268.17 \pm 5.56$ \\
\hline \multicolumn{2}{|l|}{ Sire } & & $* * *$ & $* * *$ & $* *$ \\
\hline \multicolumn{2}{|l|}{ Parities } & & $* * *$ & $* * *$ & $* * *$ \\
\hline \multicolumn{2}{|c|}{ First parity } & 382 & $1410.85 \pm 111.11^{\mathrm{c}}$ & $5.11 \pm 0.41^{\mathrm{c}}$ & $290.66 \pm 6.69^{\mathrm{a}}$ \\
\hline \multicolumn{2}{|c|}{ Second parity } & 381 & $1600.86 \pm 110.72^{\mathrm{b}}$ & $5.88 \pm 0.41^{\mathrm{b}}$ & $261.80 \pm 6.47^{\mathrm{bc}}$ \\
\hline \multicolumn{2}{|c|}{ Third parity } & 326 & $1694.73 \pm 110.90^{\mathrm{b}}$ & $6.24 \pm 0.41^{\mathrm{a}}$ & $263.33 \pm 6.63^{\mathrm{bc}}$ \\
\hline \multicolumn{2}{|c|}{ Fourth parity } & 266 & $1800.43 \pm 111.78^{a}$ & $6.59 \pm 0.41^{\mathrm{a}}$ & $259.72 \pm 7.11^{\mathrm{bc}}$ \\
\hline \multicolumn{2}{|c|}{ Fifth parity } & 219 & $1805.97 \pm 112.61^{a}$ & $6.60 \pm 0.42^{a}$ & $256.32 \pm 7.48^{\mathrm{ab}}$ \\
\hline \multicolumn{3}{|c|}{ Year-season of calving } & $* * *$ & $* * *$ & $*$ \\
\hline Winter & $1949-1958$ & 18 & $1562.41 \pm 163.83$ & $5.95 \pm 0.60$ & $239.48 \pm 21.38$ \\
\hline \multicolumn{2}{|c|}{ Dry summer } & 15 & $1691.66 \pm 173.66$ & $6.54 \pm 0.64$ & $204.56 \pm 23.45$ \\
\hline \multicolumn{2}{|c|}{ Wet summer } & 17 & $1742.60 \pm 166.19$ & $6.49 \pm 0.62$ & $230.32 \pm 21.92$ \\
\hline Winter & $1959-1968$ & 114 & $1623.12 \pm 120.96$ & $5.98 \pm 0.45$ & $245.69 \pm 10.44$ \\
\hline \multicolumn{2}{|c|}{ Dry summer } & 179 & $1623.28 \pm 118.05$ & $5.98 \pm 0.44$ & $248.71 \pm 09.52$ \\
\hline \multicolumn{2}{|c|}{ Wet summer } & 68 & $1823.70 \pm 126.07$ & $6.59 \pm 0.47$ & $242.57 \pm 12.07$ \\
\hline Winter & $1969-1978$ & 204 & $1533.37 \pm 114.25$ & $5.62 \pm 0.42$ & $267.21 \pm 08.07$ \\
\hline \multicolumn{2}{|c|}{ Dry summer } & 238 & $1501.33 \pm 113.85$ & $5.43 \pm 0.42$ & $263.55 \pm 07.95$ \\
\hline \multicolumn{2}{|c|}{ Wet summer } & 137 & $1512.85 \pm 116.39$ & $5.52 \pm 0.43$ & $265.16 \pm 08.97$ \\
\hline Winter & $1979-1988$ & 175 & $1708.29 \pm 117.94$ & $6.03 \pm 0.44$ & $268.95 \pm 09.54$ \\
\hline \multicolumn{2}{|c|}{ Dry summer } & 151 & $1678.75 \pm 117.72$ & $6.02 \pm 0.44$ & $286.85 \pm 09.57$ \\
\hline \multicolumn{2}{|c|}{ Wet summer } & 101 & $1727.40 \pm 120.23$ & $6.23 \pm 0.45$ & $281.42 \pm 10.69$ \\
\hline Winter & $1989-1999$ & 72 & $1686.19 \pm 131.68$ & $6.20 \pm 0.49$ & $320.58 \pm 14.55$ \\
\hline \multicolumn{2}{|c|}{ Dry summer } & 47 & $1796.81 \pm 137.78$ & $6.53 \pm 0.51$ & $319.05 \pm 16.21$ \\
\hline \multicolumn{2}{|c|}{ Wet summer } & 38 & $1726.71 \pm 140.08$ & $6.19 \pm 0.52$ & $308.45 \pm 17.03$ \\
\hline \multicolumn{2}{|c|}{$\begin{array}{l}\text { Linear regression on } \\
\text { lactation length }\end{array}$} & & $6.38 \pm 0.151^{* * *}$ & $\begin{array}{c}0.00435 \pm \\
0.00055^{* * *}\end{array}$ & \\
\hline \multicolumn{3}{|c|}{$\begin{array}{l}\text { Linear regression on daily } \\
\text { milk yield }\end{array}$} & & & $5.53 \pm 1.2^{* * *}$ \\
\hline \multicolumn{2}{|c|}{$\begin{array}{l}\text { Quadratic regression on } \\
\text { lactation length }\end{array}$} & & $-0.0045 \pm 0.00109 *$ & $\begin{array}{l}-0.0000178 \pm \\
0.0000041^{* *}\end{array}$ & \\
\hline \multicolumn{3}{|c|}{$\begin{array}{l}\text { Quadratic regression on } \\
\text { daily milk yield }\end{array}$} & & & $-1.21 \pm 0.3$ \\
\hline \multicolumn{3}{|c|}{ Coefficient of variation } & $37.22 \%$ & $28.8 \%$ & $27.93 \%$ \\
\hline
\end{tabular}

L.S.M = least squares means $\quad$ S.E.= standard error $n=$ total number of observations

Means without a common superscript differ significantly $(\mathrm{p}<0.05)$

(Winter $=$ November - February, Dry summer $=$ March - June \& Wet summer $=$ July - October $)$

$*=\mathrm{p}<0.05 \quad * *=\mathrm{p}<0.001 \quad * * *=\mathrm{p}<0.0001$

The overall mean for daily milk yield (Table 4) was $6.10 \pm 0.40 \mathrm{~kg}$ with a coefficient of variation of $28.87 \%$. The maximum daily milk yield was reached in the fifth 
lactation. The daily milk yield after the fifth parity was significantly $(\mathrm{p}<0.05)$ higher than the daily milk yield in the first and second lactations, while it was not significantly different ( $\mathrm{p}>0.05)$ from the daily milk yield after the third and fourth parities. The daily milk yield of the first lactation was significantly $(p<0.05)$ lower than that of other parities. The linear regression of daily milk yield on lactation length was 0.00435 , while the quadratic regression was found to be negative and small 0.000178 .

The least squares means shown in Table 4 indicate that the overall mean for lactation length was $268.17 \pm 5.56$ days with a coefficient of variation of $27.93 \%$. The first lactation period $(290.66 \pm 6.69)$ was significantly $(\mathrm{p}<0.05)$ longer than the lactation period in the second, third and fourth lactations, while it was not significantly different ( $>0.05$ ) from the lactation period following the fifth parity. The least squares analysis also revealed an increasing lactation period over years and this has become more marked from the late seventies onwards. The linear regression of lactation length on daily milk yield was positive $(5.53 \pm 1.20)$, while the quadratic regression was found to be negative $(-1.20 \pm 0.33)$.

Table 5 shows the heritability estimates for the studied traits. The results showed that the heritability estimates of reproductive traits (age at first calving and calving interval) were rather low ( $0.20 \pm 0.07$ and $0.096 \pm 0.03$, respectively). Milk yield per lactation, daily milk yield were found to have a moderate value of heritability $(0.26 \pm$ 0.06 and $0.27 \pm 0.07$, respectively), while for lactation length and dry period, they were found to be low $(0.04 \pm 0.02$ and $0.096 \pm 0.03$, respectively).

Table 5

Heritability estimates of studied traits of Butana cattle (Heritabilitäts-Schätzwerte für Merkmale der ButanaRinder)

\begin{tabular}{lc}
\hline Trait & $\mathrm{h}^{2} \pm$ S.E. \\
\hline Age at first calving & $0.19 \pm 0.07$ \\
Calving interval & $0.096 \pm 0.03$ \\
Milk yield per lactation & $0.26 \pm 0.06$ \\
Daily milk yield & $0.27 \pm 0.07$ \\
Lactation length & $0.04 \pm 0.02$ \\
Dry period & $0.096 \pm 0.03$ \\
\hline
\end{tabular}

$\mathrm{h}^{2}$ : heritability estimate, S.E.: standard error

\section{Discussion}

Reproductive traits:

Age at first calving:

The presence of significant differences between sires regarding age at first calving indicates that selection amongst Butana cattle will bring reasonable benefits. This is probably a necessary step in the process of conserving this breed for future generations.

An early age at first calving reduces the unproductive life of the cow and shortens the generation interval, thus enabling earlier performance indication. Age at first calving of indigenous cattle breeds in the tropics tends to be comparable late compared with cattle breeds in temperate countries. The overall mean age at first calving obtained in this study (45.05 months) was in agreement with the average reported by REGE (1998) who stated that the least squares mean of age at first calving in tropical cattle 
was $42.60 \pm 0.55$ months in a review study based on results from 80 reports in the literature on crossbreeding in the tropics. The mean age at first calving of the Butana found in this study is similar to those reported by EL-HABEEB (1991), SOHAEL (1984), BALA and NAGARCENKAR (1981), DAHLIN (1998) and WOLLNY et al. (1998) for Kenana, White Fulani, Hariana and Sahiwal, respectively, in the Sudan and other tropical countries (Table 6).

Crossbred cattle in the Sudan tend to show a district earlier age at first calving (OSMAN and RUSSELL, 1974 and ISHAG, 2000) (Table 6).

Reasons for differences in age of first calving are to a large degree linked to levels of feeding and husbandry, but also to selection for high performance.

Table 6

Age at first calving for indigenous dairy cattle breeds and crosses in the tropics (Erstkalbealter von Milchrinderrassen und Kreuzungen in den Tropen)

\begin{tabular}{llll}
\hline Genetic group & Country & $\begin{array}{l}\text { Age at first calving } \\
(\text { months })(\mathrm{M} \pm \text { S.E.) }\end{array}$ & Source \\
\hline Butana & Sudan & $45.05 \pm 3.56$ & Present study \\
Kenana & Sudan & $47.01 \pm 12.91$ & EL-HABEEB (1991) \\
White Fulani & Nigeria & $45.40(64$ records $)$ & SOHAEL (1984) \\
Hariana & India & $51.60 \pm 0.70$ & BALA \& NAGARCENKAR (1981) \\
Sahiwal & Pakistan & $44.10(2000$ records) & DAHLIN (1998) \\
Malawi zebu & Malawi & $49.80 \pm 9.00$ & WOLLNY et al. (1998) \\
$50 \%$ Butana x 50\% Bos taurus & Sudan & $34.20(375$ records) & OSMAN \& RUSSELL (1974) \\
25\% Butana x \% Bos taurus & Sudan & $34.40(495$ records) & OSMAN \& RUSSELL (1974) \\
$50 \%$ Kenana x 50\% Friesian & Sudan & $40.50 \pm 15.30$ & ISHAG (2000) \\
$50 \%$ Sahiwal x 50\% Friesian & India & $31.30 \pm 0.50$ & RAO \& TANEJA (1980) \\
\hline
\end{tabular}

Calving interval:

The results showed a decreasing interval with advancing parity number, and that cows in the first parity had a significantly $(\mathrm{p}<0.05)$ longer calving interval than those in the later parities. This trend could be attributed to lactation stress and continuous body growth in young growing animals and the ability of older cows to gain body weight and condition quickly after calving (YOUSIF et al., 1998).

The overall calving interval obtained in this study was very close to the optimum calving interval (12 - 13 months), and the results are comparable with those reported by EL-HABEEB (1991) for Sudanese Kenana cattle, but it were lower than those obtained by MORDE and AKINOKUN (1986), BALA and NAGARCENKAR (1981), BHATNAGAR et al. (1981) and KUMAR (1982) for White Fulani, Hariana, Sahiwal and Tharparkar cattle, respectively (Table 7).

The estimate obtained in this study also compares favourably with the value obtained for $50 \%$ crossbred cattle (Kenana x Friesian) in the Sudan by ISHAG (2000), and was lower than those obtained by OSMAN and RUSSELL (1974) and BHATNAGAR et al. (1981) for Butana x Bos taurus and Sahiwal x Brown Swiss crossbred cows, respectively.

The heritability estimates of age at first calving and calving interval in this study were rather low, indicating that most of the variation in these traits was due to environmental causes, and therefore improvement of these two reproductive traits lies mainly in better feeding and management. 
Table 7

Calving interval for indigenous dairy cattle breeds and crosses in the tropics (Zwischenkalbezeit von Milchrinderrassen und Kreuzungen in den Tropen)

\begin{tabular}{llll}
\hline Genetic group & Country & $\begin{array}{l}\text { Calving interval } \\
\text { (days) }(\mathrm{M} \pm \text { S.E.) }\end{array}$ & Source \\
\hline Butana & Sudan & $382.38 \pm 8.30$ & Present study \\
Kenana & Sudan & $446.10 \pm 126.00$ & EL-HABEEB (1991) \\
White Fulani & Nigeria & $420.98 \pm 4.11$ & MORDE \&AKINOKUN (1986) \\
Hariana & India & $570.00 \pm 12.00$ & BALA \& NAGARCENKAR (1981) \\
Sahiwal & India & $426.00 \pm 4.00$ & BHATNAGAR et al. (1981) \\
Tharparkar & India & $430(750$ cows) & KUMAR (1982) \\
50\% Butana x 50\% Bos taurus & Sudan & $436(189$ records) & OSMAN \& RUSSELL (1974) \\
25\% Butana x 75\% Bos taurus & Sudan & $448(226$ records) & OSMAN \& RUSSELL (1974) \\
50\% Kenana x 50\% Friesian & Sudan & $421.60 \pm 78.40$ & ISHAG (2000) \\
50\% Sahiwal x 50\% Brown Swiss & India & $407 \pm 2.00$ & BHATNAGAR et al. (1981) \\
\hline
\end{tabular}

Productive traits:

Lactation length

Analysis of variance showed that the parity number had a significant $(p<0.001)$ effect on lactation length. There was a decline from the first lactation up to the fourth lactation and then an increase in the remaining lactations. This finding may give some clues to the explanation of the increase in milk yield during subsequent lactations. This indicates that the increase in average daily milk yield was the cause of such variation and not the length of lactation.

Year-season of calving introduced significant $(\mathrm{p}<0.05)$ variation in lactation length. OSMAN (1972) in his study on Sudanese cattle at Ghazala Gawazat showed that year of calving had a significant effect on lactation, but season of calving had no effect. The variation in this study might be attributed to the changes in management policy related to feeding, drying off, and milking routine, disease control and changes in climatic conditions over years.

Table 8 shows lactation length mean for Butana in the present study, other indigenous breeds and crossbred cows in the tropics. The mean lactation length obtained is shorter than the optimal lactation length (305 days) generally accepted as a standard. This could be due to managerial and disease problems and it may be a true expression of the genetic potential of the herd. This is close to the findings of ALIM (1960) for Kenana, but it is higher than that reported by DEMEKE et al. (2004) for Boran cattle in Ethiopia. However, this result is lower than those reported by BHATNAGAR et al. (1981) and BALA and NAGARCENKAR (1981) for Sahiwal and Hariana cattle in India respectively.

Compared with crossbred cows in the Sudan the estimate obtained here (268,17 days) does not appear to be unduly small. ISHAG (2000) found that the average lactation length of 1008 records of 50\% crossbred Sudanese Kenana x Friesian cows was 291.3 $\pm 67.2 \mathrm{~kg}$. The estimate obtained in the current study is shorter than that reported by REGE (1998) for Bos taurus $x$ Bos indicus $F_{1}$ crossbred cows. The Author stated that lactation length of $\mathrm{F}_{2}$ cows was $8 \%$ (26 days) less than that of $\mathrm{F}_{1}$ animals. Lactation length was found to have a very low heritability estimate. This estimate does not differ 
significantly from that reported by EL-AMIN (1969) for Northern Sudanese cattle whose estimate was $0.011 \pm 0.007$.

Table 8

Lactation length means for indigenous dairy cattle breeds and crosses in the tropics (Laktationslänge von Milchrinderrassen und Kreuzungen in den Tropen)

\begin{tabular}{llll}
\hline Genetic group & Country & $\begin{array}{l}\text { Lactation length } \\
\text { (days) }(\mathrm{M} \pm \text { S.E. })\end{array}$ & Source \\
\hline Butana & Sudan & $268.17 \pm 5.56$ & Present study \\
Kenana & Sudan & $224.00 \pm 82.00$ & ALIM (1960) \\
Boran & Ethiopia & $193.00 \pm 6.00$ & DEMEKE et al. (2004) \\
Hariana & India & $311.00 \pm 18.00$ & BALA \& NAGARCENKAR (1981) \\
Sahiwal & India & $326.00 \pm 4.00$ & BHATNAGAR et al. (1981) \\
$50 \%$ Kenana x 50\% Friesian & Sudan & $291.30 \pm 67.20$ & ISHAG (2000) \\
Bos indicus x Bos taurus $F_{1}$ & Tropics & $309.00 \pm 3.60$ & REGE (1998) \\
Bos indicus x Bos taurus $F_{2}$ & Tropics & $283.00 \pm 10.10$ & REGE (1998) \\
\hline
\end{tabular}

Dry period:

The variability of dry period among parities may be attributed to improper management (milking and drying off practices) and physiological factors related to fertility. The results also showed a decreasing trend towards the optimum length.

The overall mean dry period was found to be $119.10 \pm 8.30$ days, which is longer than the optimum dry period (60 days). This result is comparable with that obtained by KHALLAFALLA (1977) and BAHATNAGAR et al. (1983) for Kenana and Sahiwal cattle respectively (Table 9). This result is similar to that calculated by ISHAG (2000) for crossbred cows (Friesian x Kenana) in the Sudan (Table 9).

The low heritability estimate for dry period obtained in the present study is consistent with those estimated by EL-AMIN (1969), KHALLAFALLA (1977) and AHMED and SIVARAJASINGAM (1998) for indigenous dairy cattle in the Sudan and in Pakistan.

Table 9

Dry period mean for indigenous dairy cattle breeds and crosses in the tropics (Trockenstehzeiten von Milchrinderrassen und Kreuzungen in den Tropen)

\begin{tabular}{llll}
\hline Genetic group & Country & Dry period (days) (mean \pm S.E.) & Source \\
\hline Butana & Sudan & $119.10 \pm 8.30$ & Present study \\
Kenana & Sudan & $174.00 \pm 5.10$ & KHALLAFALLA (1977) \\
Sahiwal & India & 139.70 (first lactation of 580 cows) & BHATNAGAR et al. (1983) \\
$50 \%$ Kenana x 50\% Friesian & Sudan & $96.31 \pm 70.16$ & ISHAG (2000) \\
\hline
\end{tabular}

In general, lactation length and dry period are influenced by milk yield and time of reconception and altogether reflect a high dependence on management and feeding levels. Therefore, any effort to improve these traits by selection within the herd will be ineffective and the most useful way is a direct selection for higher milk yield and by improving the management practices.

Milk yield:

The parity number in the present study was found to exert a significant $(p<0.001)$ effect on milk yield per lactation and daily milk yield. These findings are in agreement 
with those reported by SAEED et al. (1987) and EL-HABEEB (1991) in their studies on Kenana and Butana cattle respectively. Moreover, the results revealed that milk yield exhibited an increasing trend with advancing parity number up to the fifth lactation. These findings are in agreement with those stated by YOUSIF et al. (1998) and ISHAG (2000) in their studies on crossbred cows in the Sudan. This is probably due to the increase in body size and development of the udder during recurring pregnancies (FADLEL-MOULA, 1994).

The analysis of variance indicated significant $(\mathrm{p}<0.001)$ phenotypic variation in milk yield per lactation and daily milk yield due to the effect of year-season of calving. This variation in milk yield between periods and seasons may be due to changes in management, feed quality and quantity. Other reasons may include change in the genetic constitution of the herd.

Analysis of variance showed that the sire of cow had a significant $(\mathrm{p}<0.001)$ effect on milk yield per lactation and daily milk yield. Comparable results were reported by ELHABEEB (1991) for Butana cattle. Also it was similar to the results reported by RAO and DOMMERHOLT (1981) for Tharparkar and Sahiwal cattle in India.

The high value of the coefficient of variation for milk yield per lactation and daily milk yield in this study could be due to the variation in lactation length besides other genetic and environmental factors. The mean lactation milk yield and daily milk yield obtained in the present study were comparable with that reported by EL-HABEEB (1991) and BHATNAGAR et al. (1981) for Kenana and Sahiwal cattle in Sudan and Pakistan, respectively (Table 10). However, it was higher than those reported by DUC and TANEJA (1984) and DEMEKE et al. (2004) on Hariana and Boran cattle data in India and Ethiopia respectively.

In comparison with crossbred cows performance, the mean milk yield per lactation estimated in this study was lower than that reported by OSMAN and RUSSELL (1974) who studied data on local cattle (Butana) x Bos taurus (Holstein-Friesian, Ayrshire and Guernsey) crossbred cows at Ghurashi Farm in Northern Sudan (Table 10). The authors also noticed that all components of stress (death rate, infertility etc) increased with increasing proportions of exotic inheritance. Also this result was lower than that obtained by ISHAG (2000) (Table 10) for Kenana x Friesian crossbred cows in the Sudan, while the estimated mean milk yield per lactation was higher than that reported by WOLLNY et al. (1998) who reported that the average milk yield of Malawi zebu x Friesian crosses in small holder farms $(n=38)$ to be $1163 \pm 999 \mathrm{~kg}$ per cow per year. The higher standard deviation (999) might be due to small data size and other systematic effects.

In a review study based on results from 80 reports in the literature on crossbreeding in the tropics. REGE (1998) reported mean lactation milk yield as $2195 \pm 30.1 \mathrm{~kg}$ and $1725 \pm 105.1$ for $F_{1}$ and $F_{2}$ Bos indicus $x$ Bos taurus crossbreds, respectively. The decline in performance following inter se mating of $\mathrm{F}_{1} \mathrm{~s}$ has been attributed to a reduction in heterozygosity. SYRSTAD (1989) concluded that performance of $\mathrm{F}_{2}$ was worse than that of $F_{1}$ in all traits studied e. g. milk yield (by $452 \mathrm{~kg}$ representing 24\%). In their study of economic evaluation of crossbreeding for dairy production in Kenya KAHI et al. (1999) concluded that the Sahiwal exhibited lower breed effects for health costs, reproduction costs and feed costs compared to that of the B. taurus. That may be due to the fact that Sahiwal (B. indicus) is more adapted to the tropical stress of poor nutrition, disease challenge and heat stress than the B. taurus cattle. 
The annual milk yield (Milk yield per lactation x $365 \mathrm{x} \mathrm{CI}^{-1}$ ) in this study is $1588 \mathrm{~kg}$ while crossbreds in Sudan produced between $1751 \mathrm{~kg}$ (OSMAN and RUSSELL, 1974) and $2095 \mathrm{~kg}$ (ISHAG, 2000). This comparison does not consider the higher yield in total solid of indigenous cows and differences in husbandry cost.

Assuming that crossbred cows in the Sudan have the same low economic efficiency as the crossbred cows of Kenya and that the results for crossbred cows are taken as a true indication of the performance potential of crossbred cattle in the Sudan then it seems that the increase in production realized through crossbreeding may not be sufficient to cover the extra costs incurred through increased feed and management requirements.

Table 10

Milk yield per lactation and daily milk yield means for indigenous dairy cattle breeds and crosses in the tropics (Milchleistung von Milchrinderrassen und Kreuzungen in den Tropen)

\begin{tabular}{|c|c|c|c|c|}
\hline Genetic group & Country & $\begin{array}{l}\text { Milk yield per } \\
\text { lactation (kg) } \\
(\mathrm{M} \pm \text { S.E.) }\end{array}$ & $\begin{array}{l}\text { Daily milk } \\
\text { yield (kg) } \\
(\mathrm{M} \pm \mathrm{S} . \mathrm{E} .)\end{array}$ & Source \\
\hline Butana & Sudan & $1662.57 \pm 108.96$ & $6.10 \pm 0.41$ & Present study \\
\hline Kenana & Sudan & $1423.58 \pm 551.70$ & $5.60 \pm 1.77$ & EL-HABEEB (1991) \\
\hline Boran & Ethiopia & $529.00 \pm 65$ & $2.80 \pm 0.10$ & DEMEKE et al. (2004) \\
\hline Hariana & India & $1151.00 \pm 45.00$ & & DUC \& TANEJA (1984) \\
\hline Sahiwal (305 days) & India & $1998 \pm 23.00$ & & $\begin{array}{l}\text { BHATNAGAR et al. } \\
\text { (1981) }\end{array}$ \\
\hline $\begin{array}{l}50 \% \text { Butana x 50\% Bos } \\
\text { taurus }\end{array}$ & Sudan & 2150 (272 records) & & $\begin{array}{l}\text { OSMAN \& RUSSELL } \\
\text { (1974) }\end{array}$ \\
\hline 50\% Kenana x 50\% Friesian & Sudan & $2417.20 \pm 921.00$ & $7.34 \pm 2.44$ & ISHAG (2000) \\
\hline Malawi zebu x Friesian & Malawi & $1163.00 \pm 999.00$ & & WOLLNY et al. (1998) \\
\hline Bos indicus $\mathrm{x}$ Bos taurus $\mathrm{F}_{1}$ & Tropics & $2195.00 \pm 30.10$ & & REGE (1998) \\
\hline Bos indicus $\mathrm{x}$ Bos taurus $\mathrm{F}_{2}$ & Tropics & $1725.00 \pm 105.10$ & & REGE (1998) \\
\hline
\end{tabular}

Heritability estimates for milk yield per lactation and daily milk yield obtained in this study were consistent with those estimates obtained by EL-AMIN (1969) and ELHABEEB (1991) for Northern Sudan cattle. They are also comparable with those reported by AHMED and SIVARAJASINGAM (1998) for Sahiwal cattle in Pakistan. In a comparative study, OJANGO and POLLOTT (2002) studied the relationship between Holstein bull breeding values for milk yield derived in both the UK and Kenya using data being selected from herds (Holstein Friesian dams) containing daughters of bulls used in both countries. They reported difference in genetic variance for milk yield between the two countries, with the heritability for first lactation 305days milk yield being $0.45 \pm 0.02$ in UK and $0.26 \pm 0.06$ in Kenya. They also stated that the relative rate of response in Kenyan milk yield based on UK breeding values was estimated to be $44 \%$ of the rate expected in the UK.

The moderate value of heritabilities found for milk yield per lactation and daily milk yield indicates that there is good scope for moderate selection, even though selection is a slow process. However, in addition, there is a substantial amount of variation that is due to environment, therefore improvement of management practices must be considered when breeding policies are to be formulated.

\section{Conclusions}

It can be concluded that in some major production traits the Sudanese Butana cattle compare favourably with some of the best breeds in tropical countries and their 
performance does not fall far behind that of 50\% crossbred cattle in the Sudan, particularly if it is afforded the same level of management that crossbred cattle usually get. The $\mathrm{F}_{1}$ cows often perform relatively well but it seems difficult to establish a sustainable system of crossbreeding for further improvement. Crossbreeding Kenana and Butana with B. taurus is probably a useful strategy in riverain areas and around major towns where sufficient feed and reasonable levels of management can be provided. However, in nomadic areas probably the best strategy is to use improved Butana and Kenana bulls for crossbreeding with breeds of poor productivity in harsh conditions where B. taurus crossbreds cannot survive. This will be a useful contribution to the improvement of nutrition for people living in harsh environments.

The improvement of dairy traits in Northern Sudanese cattle is foremost a matter of improved feeding and management. These include the traits of low heritability, such as lactation length and dry period. On the other hand, milk yield per lactation and daily milk yield exhibited heritabilities of a moderate level, so that there is reasonable scope for improvement by selection, even though selection is a slow process. Also it can be concluded that this local breed constitutes an irreplaceable stock of adapted germplasm, and it must be conserved for the fact that their loss may mean the loss of valuable unique genes which cannot be easily replaced if at some future time changes in production conditions require their use.

Consideration must be given to the establishment of Butana herds for the purpose of conservation on a commercial basis. This study lends support to the view that such herds can be self-supporting provided they are well managed and the stocks are carefully selected. The estimates of productivity presented above indicate that well managed herds of Butana will not be a financial burden on the state and will help preserve the breed.

In Sudan, an economic evaluation of crossbreeding strategy using appropriate economic evaluation criteria such as used by KAHI et al. (1998) for Kenya is needed to determine whether the genetic differences between native breeds and European cattle breeds will yield greater economic benefits.

\section{Acknowledgement}

Appreciation is expressed to Prof. Faisal Awad the ex-general director of Animal Resources Research Corporation. Special thanks to the staff of Atbara Livestock Research Station. Appreciation is also expressed to the German Academic Exchange Service (DAAD) for financial support of parts of this study.

\section{References}

AHMED, M.; SIVARAJASINGAM, S.:

Analysis on the productive and reproductive traits in Sahiwal cows. Proceedings of the $6^{\text {th }}$ World Congress on Genetics applied to Livestock Production, Armidale, NSW, Australia. January Vol. 23 (1998), 339-402

ALIM, K.A.:

Reproductive rates and milk yield of Kenana cattle in Sudan. J. Agric. Sci. (Camb), 55 (1960), 183-188

BALA, A.K.; NAGARCENKAR, R.:

Evaluation of different cattle breed groups in hot humid tropics. Ph.D. Project (1981), NDRI, Karnal, India

BHATNAGAR, D.S.; NAGARCENKAR, R.; GURNANI, M.; SHARMA, R.C.:

Crossbreeding of Zebu cows with Brown Swiss. National Dairy Research Institute, Karnal, India. Annual Report 1981, 134-142 
BHATNAGAR, D.S.; TANEJA, V.K.; BASU, S.B.; MURTHY, K.M.K.:

Genetic parameters for some economic traits in Sahiwal cattle. Indian J. Dairy Sci. 36 (1983) 4, 402406

BECKER, W.A.:

Manual of Quantitative Genetics, Washington State University. Press (1975), Pullman, Washington

DAHLIN, A.

Genetic studies on Sahiwal cattle in Pakistan. Acta. Uni. Agric. Sci. J. No. 99 (1998), 72

DEMEKE, S.; NESER, F.W.C.; SCHOEMAN, S.J.:

Estimates of genetic parameters for Boran, Friesian, and crosses of Friesian and Jersey with the Boran cattle in the tropical highlands of Ethiopia: milk production traits and cow weight. J. Anim. Breed. Genet. 121 (2004), 163-175

DUC, N.V.; TANEJA, V.K.:

Comparative performance of purebred and crossbred grades in India. Indian J. Anim. Sci. 54 (1984) 11, 1023-1028

EL-AMIN F.M.:

Environmental and genetic factors influencing reproduction and milk production of Sudanese indigenous dairy cattle. M.V.Sc. Thesis (1969), University of Khartoum-Sudan

EL-HABEEB, E.A.:

Variation in reproductive and milk production traits in Butana and Kenana dairy cattle in the Sudan. M.V.Sc. Thesis (1991), University of Khartoum-Sudan

FADLEL-MOULA, A. E.:

Factors affecting reproductive and productive performance of crossbred dairy cattle in the Sudan. M.V.Sc. Thesis (1994), University of Khartoum-Sudan

HARVEY, W.R.:

Mixed Model Least-Squares and Maximum Likelihood Computer Program (1990)

ISHAG, I.A.:

Impact of genetic and non-genetic factors on productive and reproductive traits of crossbred cows raised under Sudan conditions. M. Sc. Thesis (2000), University of Khartoum-Sudan

KAHI, A.K.; KOSGEY, I.S.; CARDOSO, V.L.; VAN ARENDONK, J.A.M.:

Influence of production circumstance and economic evaluation criteria on economic comparison of breeds and breed crosses. J. Dairy Sci. 81 (1998), 2271-2279

KAHI, A.K.; THORPE, W.; NITTER, G.; GALL, C.F.:

Crossbreeding for dairy production in Kenya: parameter estimates for defining optimal crossbreeding systems. Deutscher Tropentag 1999, Berlin. Session: Sustainable Technology Development in Animal Agriculture (1999)

KHALLAFALLA, A.M.:

The reproductive performance of a herd of Kenana cattle (Northern Sudan Zebu). M.V.Sc. Thesis (1977), University of Khartoum-Sudan

KUMAR, S.:

Sources of variation in reproductive traits of Hariana and Tharparkar cows. Indian J. Anim. Sci. 52 (1982) 4, 203-209

OKOMO-ADHIAMBO, M.:

Characterization of genetic diversity in indigenous cattle of East Africa: Use of microsatellite DNA techniques. ILRI. Nairobi, Kenya (2002)

OJANGO, J.M.K.; POLLOTT, G.E.:

The relationship between Holstein bull breeding values for milk yield derived in both the UK and Kenya. Livest. Prod. Sci. 74 (2002), 1-12

MORDE, R.A.; AKINOKUN, J.O.:

Genetic parameters and factors affecting reproductive performance in White Fulani cattle in Southern Nigeria. Tropical Anim. Health and Prod. 18 (1986) 2, 81-85

OSMAN, A.H.:

Studies on Sudanese indigenous cattle. II- Environmental factors influencing reproductive rates and milk production under range conditions. Trop. Agric. (Trindad) 49 (1972),143-150

OSMAN, A.H.; RUSSELL, W.S.:

Comparative performance of different grades of European Zebu crossbred cattle at Ghurashi Farm. Sudan. Trop. Agric. (Trindad) 51 (1974), 549-559

RAO, V.P.; TANEJA, V.K.:

The role of genotype and environment in sire evaluation. National Dairy Research Institute, Karnal, Annual Report (1980), 139-144

RAO, M.K.; DOMMERHOLT, J.:

Estimation of reliable genetic parameters for production traits in tropical breeds of dairy cattle. J. Anim.

Breed. Genet. 98 (1981), 290-302 
REGE, J.E.O.:

Utilization of exotic germplasm for milk production in the tropics. Proc. $6^{\text {th }}$ World Congr. Genet. Appl. Livest. Prod. 25 (1998), 193-200

SAEED, A.M.; WARD, P.N.; LIGHT, D.; DURKIN, J.W.; WILSON, R.T.:

Characterization of Kenana cattle at Umbenein. Sudan. ILRI Research Report No. 16, Addis Ababa, Ethiopia (1987)

SOHAEL, A.S.:

Milk production potential of cattle on the Jos Plateau. Nigerian Livestock Farmer 4 (1984) 3, 13-14

SYRSTAD, O.:

Dairy cattle crossbreeding in the tropics: performance of secondary crossbred populations. Livest. Prod. Sci. 25 (1989), 97-106

WOLLNY, C.B.A.; NAMWAZA, A.G.; MAKAMBA, T.S.W.:

Zum Stand der Rinderzucht in Malawi. Arch. Tierz., Dummerstorf 41 (1998), 33-44

YOUSIF, I.A.; FADLEL-MULA, A.A.; ABU-NEKHEILA, A.M.:

Productive performance of the crossbred cattle in the Sudan. I. Lactation performance. Proc. $8^{\text {th }}$ Arab. Vet. Conf. Khartoum. March 1998, pp. 524-539

Received: 2005-02-11

Accepted: 2005-09-13

Corresponding Author

Prof. Dr. KURT J. PETERS

Department of Animal Breeding and Aquaculture in the Tropics and Subtropics,

Faculty of Agriculture and Horticulture,

Humboldt-University Berlin,

Philippstr. 13, House No. 9

10115 BERLIN, GERMANY

E-mail: k.peters@agrar.hu-berlin.de 